\section{School Natural History Societies}

THE contributions made by school societies to the spread of knowledge of their own areas is shown in booklets published by the Rugby School Natural History Society and the Biology Department at Stowe School. From Rugby comes a report of the activities during 1958 and, besides details of the work of various sections during the year, includes records of Cladocera which have been made by H. R. T. Price, and Syrphidae compiled by R. H. T. Tracy and J. Peirson. Stowe has produced "An Account of the Birds of Stowe", with records of the eighty-two species which now belong to the Stowe list. Articles on particular groups of birds which are found locally have either been taken from earlier issues of the school journal or have been specially prepared. Special tribute is paid to a former master, F. P. G. Aldrich-Blake, who appears not only to have inspired his boys but also the publication of this booklet in his honour.

\section{The Manchester Museum}

THE first annual report for $1957-58$ by Dr. D. E. Owen, the newly appointed director of the Manchester Museum (pp. 20. Manchester: The Manchester Museum, The University, 1959), reports progress in several directions. A gallery has been set apart for special temporary exhibitions, the policy to improve the display cases throughout the Museum has been accelerated and a new guide-book has been published. A bequest of Japanese material, including lacquer, ivory and bronze and collections of coleoptera and lepidoptera, has been received from the late $\mathrm{Mr}$. R. W. Lloyd. A further bequest of similar importance was the Raby collection of coins. Popular lectures on Saturday afternoons attract an average audience of sixty-one, but an experimental series on Thursday evenings was not so successful. Members of the staff continue to carry out research on the collections, and an impressive list of publications is included in the report.

\section{Work at the Royal Society Base, Halley Bay}

THE United Kingdom Antarctic Report to the fifth meeting of the Special Committee for the International Geophysical Year held in Moscow in 1958 (pp. 20. The Royal Society, 1958) includes a brief summary of matters from May 31, 1957, to May 31, 1958, dealing mainly with the work attempted at the Royal Society Base, Halley Bay. This included observations of meteorology (surface and upper air), geomagnetism, aurora, ionospheric measurements, and seismology. Over 1,250 upper air balloons were launched, some reaching heights of $20 \mathrm{~km}$., during April and May. The heights during most of the dark season were much below expectation, but increased with the return of the sun above the horizon. There were many instrumental difficulties resulting from the harsh environment but for the most part these were overcome. Tables of provisional climatic data reveal that the highest daily maxima temperatures ranged from $+2^{\circ} \mathrm{C}$. recorded in January (the only month recording a temperature above freezing-point) to $-15^{\circ} \mathrm{C}$. in August. The lowest daily minima ranged from - $51^{\circ} \mathrm{C}$. in July to $-15^{\circ} \mathrm{C}$. in December. Snow fell on 191 days during the year. The visual and all-sky camera auroral data have been compared with those in the northern hemisphere during the period of the equinoxes in an attempt to find if any simultaneous data are available. The ionospheric data have shown that the diurnal variation of the $F$ layer over Halley Bay is mainly determined by movements of ionization and not by the primary photo-ionization processes. Radio echo data obtained from auroræ have been compared with similar data from Jodrell Bank, and it is concluded that the great auroræ of the northern hemisphere are accompanied simultaneously by greatly enhanced activity of the aurora australis.

The glaciological data involved observations of the ice shelf, several hundreds of feet in thickness and partially aground, on which the station was located. The work included measurements of accumulation and ablation, and the temperature gradient within the ice, also the determination of past variations in the net accumulations. There were also frequent recordings of small seismic shocks that have been interpreted as occurring within a few degrees of Halley Bay.

\section{Scientific Research in Central Africa}

THE attractively produced and illustrated ninth annual report of the Institute for Scientific Research in Central Africa covers the year 1956 (pp. 340. Bruxelles: Institut pour le Recherche Scientifiques en Afrique Centrale, 1958) and is in three parts. The administrative report includes particulars of the management and scientific committee, the financial statement and the director's report. The second part describes the opening of the Institute's main centre at Lwiro and includes the texts of addresses on the scientific work of the Institute and other research projects relating to central Africa. The third part comprises brief summaries of the work of the Institute during the year and a list of publications by the staff of the Institute or associated workers, comprising 145 titles. Abstracts of some of these are included. In his report as director, Prof. van den Berghe refers to the completion of a study of the tsetse flies of Mutara and Ruanda-Urundi, to studies of the biology of certain noxious rodents of Kivu, of the birds of the Tshibati region and their habitats and seasons of reproduction, and on the biology of the fish of Lake Tanganyika and of its coastal fauna. Observations on the forest ecology of Mabali and the borders of Lake Tumba and the collection of a herbarium continued, as well as inquiries into the migration of natives of Ruanda-Urundi into East Africa and into the agricultural economy of Ruanda-Urundi.

\section{Oospore Germination in Albugo candida}

ANTON DE BARY's well-known illustration of oospore germination in Albugo candida (publishod in 1863), in which a sessile vesicular zoosporangium is depicted, has long held its place in standard text-books. According to T. C. Vanterpool (Can. J. Bot., 37, No. $2 ; 1959)$, no other investigation on this phenomenon in $A$. candida has ever been published. He has now demonstrated that if oospores, in hypertrophied inflorescences of rape (Brassica napus $\mathrm{L}$. var. annua Koch), are kept in a refrigerator for 21 months, liberated from the tissue by grinding, soaked for 7-10 days in water at $10-12^{\circ} \mathrm{C}$, then changed to fresh water, they will germinate. Moreover, he has shown that a second type of zoosporangium formation exists, namely, that on the rupture of the epispore, an exit tube, $1-2 \cdot 5$ times the diameter of the oospore, first grows out, the zoosporangial vesicle being then formed distally. The sessile type of germination, obtained under the same circumstances, was, however, the more common. Other interesting biological observations are also noted. 